\title{
COINING FOR A FACTION: COMPETING DEPICTIONS OF FOREIGN PEOPLES AND PLACES ON ROMAN COINAGE IN CIVIL WAR HISPANIA (RRC 468, RRC 469, RRC 470)
}

\begin{abstract}
This article presents a case study of three different coin series (RRC 468-RRC 470) minted near contemporaneously in Hispania during the latter stages of the civil war, which present strikingly different representations of foreign peoples and places. While Caesar's coin series (RRC 468) displays an image of submissive Gallic captives and a military trophy, Cnaeus Pompey Jr's two series (RRC 469=470) feature personifications of the region and local cities and depicts them working together with their Pompeian counterpart in the pursuit of victory in the area. The article incorporates hoard evidence to further develop our understanding of how a contemporary viewer might have experienced these contrasting images of foreign peoples and places. It demonstrates which would have been the more common image in circulation and provides evidence for potential audience targeting with the Pompeian coin series. In light of recent scrutiny of Pompeian patronage networks in Spain, this hoard evidence for potential audience targeting allows a new interpretation of the Pompeian coin series as targeting a potentially wavering host community to be put forward.
\end{abstract}

Keywords: Republican coinage; images of foreign peoples and places; late Republican civil wars; audience targeting; coin hoards.

\section{OVERVIEW}

$\mathrm{s}$ the site of fierce clashes at the outset and subsequently the climax of the civil war between the Caesarian and Pompeian factions, the provinces of Hispania Citerior and Hispania Ulterior were the recipients of a myriad of competing messages in various media that encouraged the support of one side or the other. ${ }^{1}$ The public projection of different messages by the two factions extended to the highly portable medium of coinage, which was produced regularly by mints alongside the various armies in the field. ${ }^{2}$ Images of foreign peoples and places on coinage

\footnotetext{
${ }^{1}$ E.g. BHisp. 22.1 - Caesar sends envoys to the city of Urso in Hispania Ulterior to emphasise the cruelty of Pompeian troops to try and gain the city's backing; BHisp. 22.1 - Cnaeus Pompey sends a letter to the same city claiming that his army would not allow cities that were supportive of him to be conquered and that he had been unable to defeat Caesar as yet only due to Caesar's refusal to engage in open confrontation.

2 On the projection of various messages on coinage by the various civil war factions of the late Republic in different contexts, see for example NEWMAN 1990; HOLLSTEIN 1994; CHAVES TRISTÁN 2005; KOPIJ 2012, 2015. CHAVES TRISTÁN 2005, 235-237 describes the coinage of
}

\section{Ellen MACDOUGALL}

Goethe University Frankfurt am Main ellenmacdougall@googlemail.com

DOI: $10.14795 /$ j.v7i 2.528

ISSN $2360-266 \mathrm{X}$

ISSN-L 2360 - 266X 
saw a particularly strong upturn in coin type usage during the civil war. ${ }^{3}$ This study focuses on three near contemporaneous coin series (RRC 468-470) from the final months of the civil war conflict in Hispania that demonstrate differing usage of this imagery by both sides within the same regional context. Cnaeus Pompey $\mathrm{Jr}$ and the remnants of the Pompeian forces had regrouped in the Iberian Peninsula in late 46 B.C. following defeat at Thapsus while Caesar pursued them there at the beginning of 45 B.C. As part of their coinage output in Hispania in this period, one Caesarian coin series (46-45 B.C.) and two Pompeian coin series (46-45 B.C.) were minted that incorporate strikingly different figural representations of foreign peoples and places. ${ }^{4}$ While Caesar's coinage displays an image of passive and submissive Gallic captives alongside a military trophy, ${ }^{5}$ Cnaeus Pompey's two series feature personifications of the region and local cities and shows them working in tandem and often on an equal footing with their Pompeian counterpart in the pursuit of victory. ${ }^{6}$

This study is the first to highlight the differing usage of images of foreign peoples and places by Caesarian and Pompeian moneyers in Hispania in this period. Previous scholarship discussing the coinage has primarily focussed on the two Pompeian coin series and upon interpreting the significance of its imagery without consideration of hoard evidence. ${ }^{7}$ While Luis Amela Valverde brought hoard evidence into his discussion of RRC 469 , his overall interpretation of the series was rooted in the traditional view that the imagery appealed to pre-existing strong networks of Pompeian clientele. ${ }^{8}$ This study will present a new interpretation of the imagery in light of recent challenges to this traditional viewpoint.

Hoard evidence provides a significant opportunity to develop discussions of how a contemporary viewer might have responded to these competing images of foreign peoples and places. This study draws together a large body of hoard evidence from the Iberian Peninsula between the mid40s B.C. and the early to mid-Augustan period to highlight the comparative quantitative strength of the Caesarian and Pompeian images of foreign peoples and places produced on coinage minted in the region. ${ }^{9}$ Close study of the coin hoards from the 40s B.C. allows us to gain an understanding of their initial contemporary circulation patterns in the Iberian Peninsula. This provides evidence for a potentially deliberate initial audience targeting on the part of the Pompeian faction beyond what can be inferred purely from analysing the choice of image compositions in these two coin series.

\section{OVERVIEW OF COIN TYPES}

Caesar's RRC 468 denarii series (46-45 B.C.) shows a military trophy on the reverse adorned with a Gallic horned

Pompey's children in Hispania in the run up to Munda specifically as "una bandera propagandistica" rather than coinage that carried any significant economic weight in the financing of the contest between the two sides.

3 MACDOUGALL 2017.

${ }^{4}$ RRC 468.1-2, RRC 469.1a-1e, RRC 470.1a-1d.

${ }^{5}$ RRC 468.1-2.

${ }^{6}$ RRC 469.1a-1e; RRC 470.1a-1d.

7 E.g. BUTTREY 1960; WELCH 2002, 18-19; BERDOWSKI 2017.

8 VALVERDE 2013

9 For a full list of the hoards collated in the study, see Table 1 in Section 3. helmet, shields and carnyces along with a male and female Gallic captive figure alongside it (Fig. 1). ${ }^{10}$ On one version of the type (RRC 468.1), the Gallic female figure sits to the left of the trophy resting her head on her right hand in a gesture commonly associated with mourning while the Gallic male captive sits on the right hand side with his hands bound behind his back. ${ }^{11}$ A second variation (RRC 468.2) shows a slight difference in the shield types and has the male figure kneeling on the left hand side and looking up towards the military trophy. ${ }^{12}$ In both cases, the accompanying legend of CAESAR identifies him as the coin's issuing authority. While the slight stylistic differences between the two variations have led to conclusions that they were minted either at marginally different times or perhaps at different Spanish mints, it is nevertheless appropriate to attribute both types from the series to Caesar's four month long campaign against the Pompeian forces in the Iberian Peninsula. ${ }^{13}$

The first Pompeian coin type under consideration (RRC 469) features in a series of denarii minted by Cnaeus Pompey and M. Poblicius (46-45 B.C.). ${ }^{14}$ The reverse of the denarii shows a female figure carrying two spears in her left hand along with a round shield (Fig. 2). The combination of her attributes and gender suggest that she should be considered as a personification of Hispania. ${ }^{15}$ A male soldier stands on a ship's prow to the right of the scene. He has been identified variously as just a "soldier"16, a representation

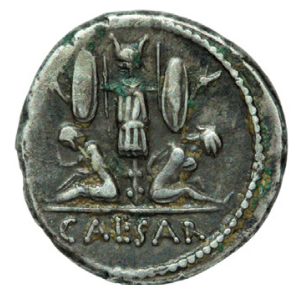

Image reproduced with

permission from Friedrich-

Alexander-Universität

Erlangen-Nürnberg, Collection Heerdegen $\mathrm{H}$ 284, photographer - Andreas Murgan
Fig. 1. RRC 468.1.

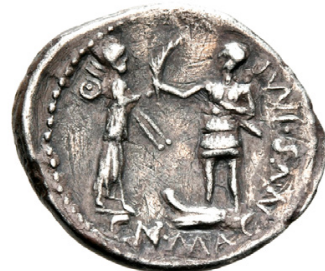

Fig. 2. RRC 469.1a. Image reproduced with permission from Das Digitale Münzkabinett der Johannes Gutenberg-

Universität Mainz (JGU Mainz, Alte Geschichte Inv. 202)

\footnotetext{
${ }^{10}$ While CRAWFORD 1974, 479 dates RRC 468 to 46-45 B.C., I agree with CHAVES TRISTÁN 2005, 230 that a date early in 45 B.C. seems more likely given that Caesar waited for the election at the end of 46 B.C. before departing for Hispania and while he travelled quickly, his journey still took 27 days to complete. VALVERDE 2010, 25 also dates it to 45 B.C. rather than 46 B.C.

11 The identification of the female captive figure as Hispania (per GRUEBER 1970, 369) seems unlikely (WOYTEK 2003, 304) and she is otherwise almost universally identified as Gallic (CRAWFORD 1974, 479; SEAR 1998, 40-41; WOYTEK 2003, 300).

12 RRC 468.2.

13 SEAR 1998, 40. WOYTEK 2003, 301 suggests that RRC 468.1 was minted later than RRC 468.2 because of simplifications evident in the composition of RRC 468.1. Nevertheless on the basis of hoard evidence, Ibid., 303-304 agrees with attributing the minting of both to the Iberian Peninsula during Caesar's campaigns there at the end of the civil wars. Ibid., 304 speculates that Obulco could have been one of the mints given that it appears to have been the Caesarian headquarters at the outset of the campaign but stresses that it cannot be more securely attributed than any other possible mint location. 14 RRC 469.1a-1e.

5 BUTTREY 1960, 288; ARCE 1980, 82; SEAR 1998, 35; WOYTEK 2003, 282; BERDOWSKI 2017, 169 amongst others identify the figure as a personification of Hispania. For further on the representation of Hispania, see ARCE 1980.

16 CRAWFORD 1974, 479
} 
of "part of the Pompeian armies that came to Spain from Africa to save the peninsula"17 or even as Cnaeus Pompey himself. ${ }^{18}$ Regardless of applying either a general or more specific identification to the figure, he nevertheless seems to broadly symbolise the arrival of the Pompeian forces in the region. ${ }^{19}$ Most recently, Piotr Berdowski interpreted the image as a direct commemoration of the appointment of Cnaeus Pompey to the command of the on-going revolt in the region. ${ }^{20}$

Depending on the quality of the extant example, Hispania either holds a palm leaf in her right hand while the soldier's arm reaches out or both figures clasp the palm leaf with their right hands at the same time. The former example allows for an interpretation where the Pompeian soldier is either reaching for the palm branch offered by Hispania or he has just completed the action of giving the branch to her. ${ }^{21}$ Bernhard Woytek prefers to give primacy to the composition present in the finer examples where both Hispania and the male figure simultaneously clasp the palm leaf. ${ }^{22}$ With this composition, he argues that the question of who gives the branch to whom seems misguided and that instead the composition better expresses the cooperation or symmachia between Hispania and the representative of the Pompeian forces. $^{23}$ This sense of a cooperative victory between the Pompeians and Hispania is arguably equally as valid for the composition where Hispania holds the branch alone, with both figures reaching out their right hands in the process of transferring the palm branch. The right hand itself was the hand of fides and an important symbol of oath taking and partnership. $^{24}$

The second Pompeian coin series (RRC 470) was minted by Cnaeus Pompey and M. Minatius Sabinus and incorporates four different compositions featuring personifications of local places from the region. ${ }^{25}$ The series

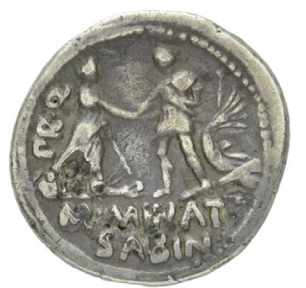

Fig. 3. denarius of Cnaeus Pompeius and M. Minatius Sabinus (46-45 B.C.), RRC 470.1a, image reproduced with permission from Münzsammlung des Seminars für Alte Geschichte Albert-LudwigsUniversität Freiburg i.Br. ((CC) BY-NC-SA, Seminar für Alte Geschichte, Albert-Ludwigs-Universität Freiburg, https://ikmk.uni-freiburg.de/ object?id=ID3155)

\footnotetext{
17 BUTTREY 1960, 94 voices strong reservations about identifying him as Cnaeus Pompey due to the lack of living Romans on Roman coinage prior to Julius Caesar.

18 WOYTEK 2003, 288.

19 BERDOWSKI 2017, 170

20 Ibid., 172.

${ }^{21}$ Ibid. notes that "if it is the soldier handing the palm branch to the female, the most natural interpretation would appear to be to understand it as an announcement of victory over Caesar. If the intention of the moneyer was the reverse, it would be possible in this scene to see (similarly to the denarii of Minatius) an allusion to the passing of command over the revolt to Cnaeus."

${ }^{22}$ WOYTEK 2003, 289.

23 Ibid.

${ }^{24}$ BRILLIANT 1963, 38. See for example Livy, 23.9.3.

25 RRC 470.1a-1d.
}

appears to have been minted at multiple mints in the region although attributing them to specific ones has been the subject of considerable debate. ${ }^{26}$ The first of the compositions from the series shows a mural crowned female figure armed with a spear and shaking right hands with an armed soldier on the right who is in the process of disembarking from a ship adorned with an aplustre, a symbol of victory (Fig. 3). ${ }^{27}$ Scattered weapons are shown around the female figure in an allusion to the contemporary struggle and turmoil in the province.

Previous scholarship has identified her variously as a personification of Cordoba, ${ }^{28}$ Hispania/Baetica ${ }^{29}$ or an unidentified "Spanish city". ${ }^{30}$ Identifying her specifically as Hispania or Baetica seems unlikely due to her representation with a mural crown and its strong association with cities rather than regions. ${ }^{31}$ Furthermore, Theodore Buttrey could find no source references to Baetica prior to 27 B.C. when the Iberian provinces were reorganised into Baetica, Tarraco and Lusitania that further makes an identification of Baetica unlikely. ${ }^{32}$ However, no accompanying legend on the reverse allows us to directly confirm another identity for her beyond that of a local city. Source references to the specifics of Cnaeus Pompey's activities in Hispania in this period of the civil war are sparse, with the majority of sources only picking up on activities in the region upon Caesar's arrival. ${ }^{33}$ This lack of information makes it extremely difficult to securely classify her beyond identifying her as a local city. ${ }^{34}$

Berdowski suggests that the difficulty with specifically identifying the personification would have extended to a contemporary viewer. ${ }^{35}$ Indeed, the ambiguity of the composition could perhaps have been a deliberate ploy to allow for contemporary viewers from a variety of local communities to identify the figure with their own city. ${ }^{36}$ The fact that the personification of the Hispanic city is shown armed suggests an involvement in the military struggle in the region. ${ }^{37}$ The composition closely echoes the theme of partnership between the local region and the arriving Pompeian forces that is evident in Poblicius and Pompey's Hispania type, with the two figures similarly clasping right hands and standing on a largely equal footing.

A further composition from the same series depicts a mural crowned personification of an unknown Hispanic city approaching a Pompeian soldier who turns his head in

\footnotetext{
${ }^{26}$ BUTTREY 1960, 82. See also WOYTEK 2003, 292-293.

27 RRC 470.1a.

28 BUTTREY 1960, 88, CRAWFORD 1974, 480.

29 SYDENHAM 1952, 173, GRUEBER 1970, 366.

${ }^{30}$ CODY 2003, 120.

31 WOYTEK 2003, 292 was sceptical of the identification of her as Cordoba.

32 BUTTREY 1960, 88.

33 Ibid., 91. B Afr. 1 only referenced in general that Cnaeus Pompey had "mustered a good large force, partly by entreaties, partly by violent measures, he was now playing havoc with the province. In these circumstances some states sent reinforcements of their own accord, while...some shut their gates against him" (trans. Way).

${ }^{34}$ Cass. Dio 43.30.

35 BERDOWSKI 2017, 169.

36 Compare, for example, with RRC 419.2 where the mural crowned personification of Alexandria is clearly labelled as such in the accompanying legend.

37 VALVERDE 1990-1991, 188 sees the armed Spanish figures as allegories of the Pompeian army or the recruitment of Hispanic troops performed by the figure.
} 
acknowledgement of her approach. ${ }^{38}$ He is in the process of receiving a shield from a kneeling mural crowned personification of a further Hispanic city. ${ }^{39}$ It is impossible for us to securely identify the cities on display given the lack of accompanying legend and the fragmentary source records regarding Cnaeus Pompey's activities in this period. The inclusion of multiple personifications of cities suggests, however, that the scene could refer to several cities that either came over to Pompey of their own accord or instead were taken by force. ${ }^{40}$

While it is now impossible to definitively identify the two Hispanic cities, it is possible to conclude that an ancient viewer would likely have discerned differences in the relationships between the figures and local communities represented. The personification on the left stands alone and uninhibited. She is an active figure in the scene, walking towards the male figure and raising her hand in greeting. While he is the only armed person in the scene and is therefore the dominant figure, he turns to acknowledge her approach and they are on an equal footing. This suggests that she might personify a city supportive of the Pompeian cause. In contrast with the freestanding personification on the left, the personification on the right defers to the authority of the soldier, kneeling and presenting him with a shield in a gesture of supplicatio. ${ }^{41}$ She directs her gaze up towards him, however he fails to meet it, with his face turned instead towards the approaching woman. However, even when differentiating between the two personifications, and showing one in a lower and more submissive position, explicit captive iconography clearly indicative of her defeat is not used. Herbert Grueber, Jane Cody and Francisca Chaves Tristán all suggest that the shield that she carries was in fact indicative of an offer of support for the Pompeian cause from that city. ${ }^{42}$ Most recently, Berdowski proposed that the handing over of the shield could commemorate the handing over of the command of the Hispanic revolt to Cnaeus Pompey. ${ }^{43}$ The male figure certainly reaches out and holds it, as if preparing to accept the offered shield even if he does not interact with the personification through his gaze.

M. Minatius Sabinus produced a third composition in this series featuring personifications of local places. ${ }^{44}$ Close analysis of the composition is unfortunately hampered by the quality of the extant examples. The reverse shows a mural crowned female figure on the left hand side offering a laurel branch to a cuirassed male figure standing in the centre of the composition. ${ }^{45}$ A sword hangs from his left hand side

\footnotetext{
38 RRC 470.1b. SYDENHAM 1952, 173, GRUEBER 1970, 366 identify her as Baetica although this seems unlikely - see discussion above. CODY 2003, 114-115 identified her as a "Spanish city" and the kneeling female figure on the right as "a personification of Spain" although the latter identification seems unlikely given the use of the mural crown.

39 CRAWFORD 1974, 480 labelled both as personifications of a "Spanish city". BUTTREY 1960, 92 was likewise unable to securely identify these cities

40 Cass. Dio 43.30 referred only to the fact that Cnaeus Pompey "proceeded fearlessly through the country, gaining some cities of their own accord, and others against their will, and seemed to surpass even his father in power" (trans. Cary) rather than naming specific cities.

${ }^{41}$ CODY 2003, 114-115 identified it as supplicatio.

42 GRUEBER 1970, 366-367; CODY 2003, 114; CHAVES TRISTÁN 2005, 230 .

43 BERDOWSKI 2017, 172

44 RRC 470.1c

45 SYDENHAM 1952, 173; GRUEBER 1970, 367 identify it as laurel.
}

and he is shown leaning on a spear and facing towards the figure that offers him the branch. A further mural crowned female figure approaches from the right with an object slung over her back.

Laurel had dual associations with both the announcement of peace following conflict and with military victory. ${ }^{46}$ In presenting the laurel branch to the soldier, the personification on the left therefore appears to be marking an end to hostilities and an acknowledgement of Pompeian victory. This impression of the personifications participating in the proclamation of Pompeian victories in the region is furthered when we consider the figure on the right. She reaches her right arm up towards the male figure's head in a gesture of crowning and carries a military trophy over her shoulder. ${ }^{47}$ This aspect of the composition has echoes of other image types on Republican coinage that show Mars carrying a military trophy over his shoulder in celebration of a victory. $^{48}$

The final composition from the series is a variation on this type where the personification of the Hispanic city is shown shaking right hands with the Pompeian soldier in the centre rather than presenting a laurel branch to him. ${ }^{49}$ The unshackled and freestanding nature of the personifications alongside their clasping of right hands once more suggests an element of partnership in the success rather than them being the recipients of Pompeian domination through victory.

The Caesarian and Pompeian coin series thus present strikingly different conceptualisations of foreign peoples and places contemporaneously on coinage produced in the Iberian Peninsula. While the Caesarian series emphasises passive submission in the figures of the Gallic captives, the two Pompeian series demonstrate clear sensitivity towards regional communities through the use of personifications of local places and areas. ${ }^{50}$ Rather than conceptualising these personifications as figures to be dominated in anticipation of Pompeian victory in the area, the compositions consistently present the region and certain cities within it as near equals and key partners in their pursuit of success. Nevertheless, examining these images on a typological level alone does not allow a sense of either the comparative frequency of these images in circulation or their initial circulation patterns in practice. Analysis of contemporary hoard evidence allows the relative quantitative strengths of the Pompeian and Caesarian coin series to be demonstrated. Hoard evidence also provides evidence for a potentially deliberate initial audience targeting on the part of the Pompeian faction beyond what can be inferred purely from the choice of image compositions in the two Pompeian coin series under discussion.

\section{ANALYSIS OF HOARD EVIDENCE}

31 coin hoards (6824 Roman coins) from the Iberian Peninsula were collated that had an estimated closure

\footnotetext{
CRAWFORD 1974, 480 was less specific and identifies it as just a "branch".

46 Plin. HN 15.40.133-134, Livy, 5.28.

47 SYDENHAM 1952, 173; GRUEBER 1970, 367; CRAWFORD 1974, 480.

48 See for example RRC 306.1.

49 RRC 470.1d.

50 Although this conceptualisation of 'local' is nevertheless framed within the Hellenistic tradition of personifications as female figures with attributes e.g mural crowns for personifications of cities.
} 
Table 1 - list of hoards collated for study ordered by estimated decade of closure (40s-10s B.C.)

\begin{tabular}{|c|c|c|}
\hline Hoard & Total number of known coins & Estimated decade of closure \\
\hline Cortijo de los Cosmes $1983^{51}$ & 157 & 40s B.C. \\
\hline El Centenillo (Primavera 1911) ${ }^{52}$ & 57 (59 including non-Roman coinage) & 40s B.C. \\
\hline Jaén ¿Mentesa? (¿1953?) $)^{53}$ & 69 (70 including non-Roman coinage) & 40s B.C. \\
\hline Almuñécar (Sexsi) ${ }^{54}$ & 42 (only 28 available for study) & 40s B.C. \\
\hline Fuente de Cantos (before 1955) 55 & 387 (390 originally) & 40s B.C. \\
\hline El Raso $1974^{56}$ & 5 & 40s B.C. \\
\hline Sao Mamede de Ribatua $1892^{57}$ & 42 (43 including non-Roman coinage) & 40s B.C. \\
\hline Sendinho da Senhora $1949^{58}$ & 76 (originally 100 ) & 40s B.C. \\
\hline Empúries $1913^{59}$ & 45 & 40s B.C. \\
\hline Llíria $^{60}$ & 982 & 40s B.C. \\
\hline Provincia de Córdoba (before 1834$)^{61}$ & 130 & 40s B.C. \\
\hline Menoita $1942^{62}$ & 102 (originally over 280 ) & 40s B.C. \\
\hline Los Tejares, Cerro del Berrueco (c. 1909)63 & 15 (17 including non-Roman coinage, originally 200 or 283 coins) & 40s B.C. \\
\hline Saō Bartolomeu de Meruge $1850^{64}$ & 10 (over 200 originally) & 40s B.C. \\
\hline Monte Coutado ${ }^{65}$ & 4 (400 originally) & 40s B.C. \\
\hline Castilblanques $^{66}$ & 6 (150-200 originally) & 40s B.C. \\
\hline Torre Milanera $^{67}$ & 86 (296 originally) & 40s B.C. \\
\hline Rua $1878^{68}$ & 4 (over 400 originally) & 40s B.C. \\
\hline Izeda ${ }^{69}$ & 4 & 40s B.C. \\
\hline Guiaes (c. 1908) $)^{70}$ & 10 & 30s B.C. \\
\hline Monte Mozinho ${ }^{71}$ & 4 & 30s B.C. \\
\hline Castro de Alvarelhos $^{72}$ & 3454 & 20s B.C. \\
\hline Cortijo del Alamo $1957^{73}$ & 131 & 20s B.C. \\
\hline Citania de Sanfins ${ }^{74}$ & 306 & 20s B.C. \\
\hline Herdade da Gralheira ${ }^{75}$ & 126 (originally over 1000) & 20s B.C. \\
\hline Ramallas (Zamora) ${ }^{76}$ & 27 & 20s B.C. \\
\hline Abertura $^{77}$ & 38 & 10s B.C. \\
\hline Albacete $1906^{78}$ & 323 (403 including non-Roman coinage) & 10s B.C. \\
\hline Barroca do Antero ${ }^{79}$ & 81 & 10s B.C. \\
\hline Penamacor ${ }^{80}$ & 84 & 10s B.C. \\
\hline Santo Estévāo ${ }^{81}$ & 16 & 10s B.C. \\
\hline
\end{tabular}

${ }^{51}$ CHAVES TRISTÁN $1996,414-429$.

${ }^{52}$ Ibid., 430-433.

${ }^{53}$ Ibid., 434-440.

${ }^{54}$ Ibid., 441-443.

${ }^{55}$ CHINCHILLA SANCHEZ 1982; BLÁZQUEZ CERRATO 1987-1988, 132, no. 86, 2002, 39-45; VILLARONGA 1993, 57, no. 140; CHAVES TRISTÁN 1996, 383-400.

${ }^{56}$ VILLARONGA 1993, 57, no. 138; BLÁZQUEZ CERRATO 2002, 49.

${ }^{57}$ CENTENO 1987, 134-135, no. 76.

${ }^{58}$ RRCH 388; VILLARONGA 1993, 58, no. 147; BARBOSA 1998-2002, 6061, no. 38.

${ }^{59}$ CAMPO 2002; VALVERDE 2010, 13.

${ }^{60}$ RRCH 397; RIPOLLĖS 1982, 38-42, VILLARONGA 1993, 56, no. 132;

HURTADO MULLOR/LLEDÓ CARDONA 2005.

${ }^{61}$ RRCH 404; MOMMSEN 1870, 145; VILLARONGA 1993, 60, no. 158;

CHAVES TRISTÁN 1996, 446.

${ }_{62}$ RRCH 414; VILLARONGA 1993, 60, no. 162.

${ }^{63}$ VILLARONGA 1993, 59, no. 150; BLÁZQUEZ CERRATO 2002, 52-53.

${ }^{64}$ VILLARONGA 1993,57 , no. 143; BARBOSA 1998-2002, 56-57, no. 33; DE
ALARCĀO 1999, 7.

${ }^{65}$ RRCH 372; BARBOSA 1998-2002, 57-58, no. 34; VALVERDE 2010, 10

${ }^{66}$ GOZALBES 2001; VALVERDE 2010, 14.

${ }^{67}$ CHAVES TRISTÁN 1999, 142-144; MIL.

${ }^{68}$ RRCH 372; RUA.

${ }^{69}$ CENTENO 1987, 91, no. 45.

${ }^{70}$ Ibid., 90, no. 44; BLÁZQUEZ CERRATO 1987-1988, 134, no. 99.

${ }^{71}$ MOZ; VILLARONGA 1993, 61, no. 164.

${ }^{72}$ BLÁZQUEZ CERRATO 1987-1988, 138, no. 106; CENTENO 1987, 45-55.

${ }^{73}$ RRCH 464; CHAVES TRISTÁN 1996, 447-459.

${ }^{74}$ CENTENO 1987, 74-79; BLÁZQUEZ CERRATO 1992, 25-35.

${ }^{75}$ BARBOSA 1998-2002, 71-73, no. 52.

${ }^{76}$ RRCH 484; BLÁZQUEZ CERRATO 2002, 35-37.

77 BLÁZQUEZ CERRATO 2002, 33-35.

${ }^{78}$ VILLARONGA 1971-1972.

79 BARBOSA 1998-2002, 66-68, no. 46.

${ }^{80} \mathrm{RRCH}$ 502; PEN.

${ }^{81}$ CENTENO 1987, 132, no. 74; BARBOSA 1998-2002, 74, no. 54. 
date between the minting dates of RRC 468-470 and approximately 10 B.C. (Table 1 ). All bar seven of the hoards examined contained examples of RRC 468 or RRC 469$470 .^{82}$ The dataset presented particular challenges given that many of the hoards are incompletely catalogued or reported, particularly those with estimated closure dates in the 40 s B.C. ${ }^{83}$ Nevertheless, the dataset presents significant opportunities for a more nuanced understanding of how an ancient viewer would have experienced these contrasting images.

2224 of the coins appeared in 19 hoards with a closure date estimated in the 40s B.C. Within the hoard material from this decade, Caesar's Gallic captives and trophy series (RRC 468) appear at a comparatively high overall frequency of approximately $5.17 \%$. RRC 468.1 came to approximately $4.5 \%$ and RRC 468.2 comprised approximately $0.67 \%$ of the hoard evidence respectively. This variation in the initial frequency between the two types from the series in hoard material from the 40s B.C. is significantly higher than Woytek's overall estimate that RRC 468.1 tends to be about three times as frequent as its earlier counterpart RRC 468.2. ${ }^{84}$ M. Poblicius and Cnaeus Pompey's coin series showing a personification of Hispania greeting a Pompeian soldier and clasping a palm branch (RRC 469) appears at an overall frequency of approximately $1.26 \%$ in hoard material with a closure date in the 40s B.C. One of the variations from Cnaeus Pompey and M. Minatius Sabinus' coin series (RRC 470) appears as a single example in the Almuñécar (Sexsi) hoard. This is the only example from the series to feature in hoard material with a closure date in the 40s B.C. and it appears at an extremely low overall frequency of $0.04 \% .{ }^{85}$

The initial evidence from the hoard material from the 40s B.C. suggests that the Caesarian image of the submissive Gallic captives and military trophy $(5.17 \%)$ was more than

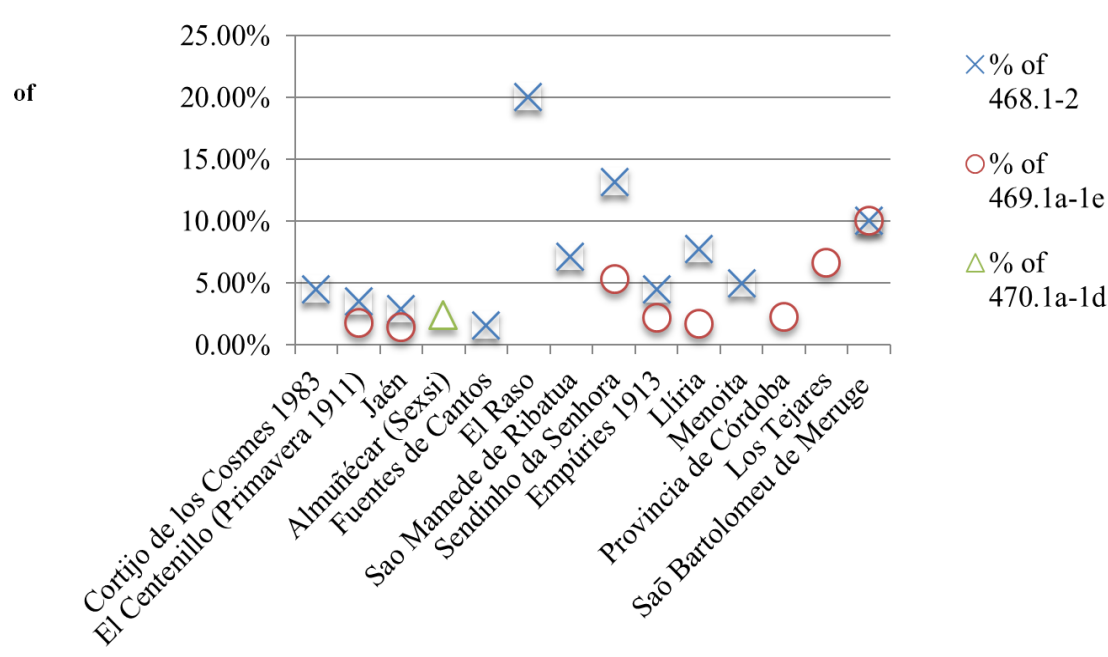

Fig. 4. chart showing percentage of RRC 468.1-2, RRC 469.1a-1e, RRC 470.1a-1d in hoards from the Iberian Peninsula with a 40s B.C. closure date

\footnotetext{
82 Izeda, Rua 1878, Torre Milanera, Castilblanques, Monte Coutado, Monte Mozinho and Santo Estévāo do not contain any known examples of RRC 468470 in their current states of cataloguing.

${ }^{83}$ VALVERDE 2010, 8. The incomplete hoards are indicated in Table 1.

84 WOYTEK 2003, 301.

${ }_{85}$ They appear at a frequency of $2.38 \%$ within just the Almuñécar (Sexsi)) hoard.
}

four times as common as M. Poblicius and Cnaeus Pompey's Hispania and Pompeian soldier type (1.26\%). ${ }^{86} \mathrm{M}$. Minatius Sabinus and Cnaeus Pompey's variations (RRC 470) showing personifications of Spanish cities and Pompeian soldiers are dwarfed by the other two coin series, with only one example featuring in a single hoard (Almuñécar (Sexsi)) at an overall decade frequency of $0.04 \%$ but at an individual hoard level of approximately $2.38 \%$ (Table 1 ). The variations in the approximate frequency of all of the coin series between the individual coin hoards from the 40s B.C. that feature examples of them are detailed in the accompanying chart (Fig. 4). The dramatically high frequency level for RRC 468 shown on the chart for the El Raso hoard is of course an anomalous and misleading result given that the coin hoard itself includes only five coins in total (Table 1). Similarly, the strong percentage levels shown for RRC 469 in the Los Tejares hoard and for both RRC 468 and RRC 469 in the Saō Bartolomeu de Meruge should be approached with caution given that so few coins are catalogued from their original numbers (Table 1 ).

Two-coin hoards (14 coins) were collated for this study with a closure date in the 30s B.C. and five with estimated burial dates in the 20s B.C. (4044 coins) (Table 1). Data from the two decades is considered in a grouping together given that only two hoards of a small size were catalogued from the 30s B.C. The frequency of Caesar's Gallic captive and trophy coin series (RRC 468) remains within an order of magnitude of the frequency in hoard material with a closure date in the 40s B.C., increasing slightly to an approximate frequency of 5.59\%. RRC 468.1 comprises $4.36 \%$ while RRC 468.2 comes to $1.23 \%$ of the total from hoards that are believed to have been concealed in the 30s and 20s B.C. M. Poblicius and Cnaeus Pompey's Hispania and Pompeian soldier type (RRC 469) drops slightly to approximately $1.08 \%$ of the total hoard material. M. Minatius Sabinus and Cnaeus Pompey's series featuring personifications of Spanish cities (RRC 470) once again appears in only a single coin hoard (Castro de Alvarelhos) from northern Portugal. The Castro de Alvarelhos hoard includes one example of the composition showing a Pompeian soldier receiving a shield from a Spanish city and one specimen depicting a Pompeian soldier being presented with a laurel branch and military trophy by two personifications of Spanish cities. These collectively come to only $0.05 \%$ of the total hoard material collated from the 30 s and 20s B.C. ${ }^{87}$

The frequency of the Caesarian Gallic captive and trophy series (RRC 468) increases slightly (5.59\%) when compared to the earlier hoard material although it remains within an order of magnitude of its frequency in the initial 40s B.C. hoards

\footnotetext{
${ }^{86}$ Although still nowhere near as sizeable a Caesarian issue as RRC 443, per VALVERDE 2010, 24. Ibid., 25-26 also states that RRC 468 was considerably larger than RRC 469 or RRC 470.

87 1.22\% of just the Castro de Alvarelhos hoard.
} 


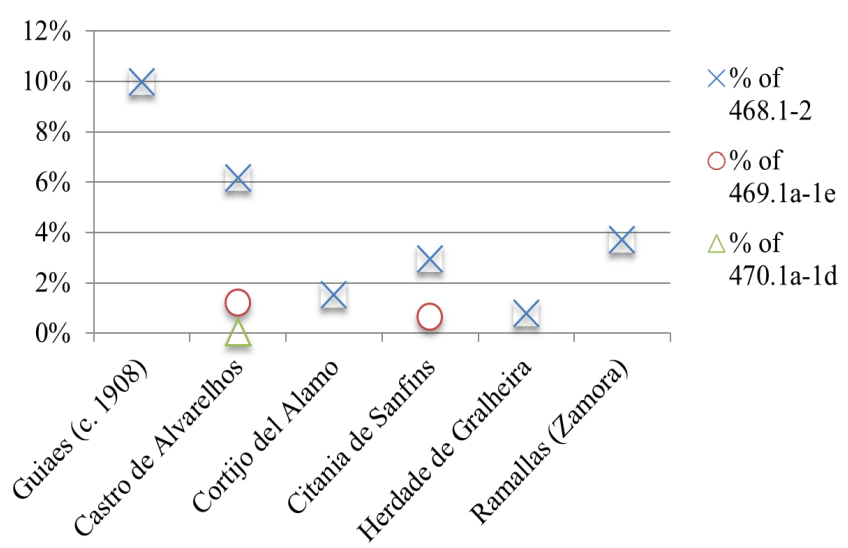

Fig. 5. chart showing percentage of RRC 468.1-2, RRC 469.1a-1e, RRC 470.1 a-1d in Iberian hoards with a 30s B.C. or a 20s B.C. closure date

(5.17\%). It is especially frequent in the Castro de Alvarelhos hoard as indicated in the breakdown of the 30s and 20s B.C. hoards that contain examples of RRC 468-470 (Fig. 5). While the Guiaes hoard from the 30s B.C. does have an individual frequency for RRC 468 of $10 \%$, this is an anomalous indicator of frequency as only 10 coins are present in the hoard compared to 3454 in Castro de Alvarelhos (Table 1). M. Poblicius and Cnaeus Pompey's Hispania and Pompeian soldier type (RRC 469) declines slightly in frequency from $1.26 \%$ in the 40 s B.C. material to $1.08 \%$ and is under onefifth of the total frequency for the Caesarian type in the same period. M. Minatius Sabinus and Cnaeus Pompey's series depicting personifications of Spanish cities (RRC 470) continues to feature at an extremely low frequency level and stays broadly stable at $0.05 \%$ in the 30 s and 20 s B.C. material compared to $0.04 \%$ in the 40 s B.C.

Five coin hoards (542 Roman coins) from the Iberian Peninsula were collated with a closure date estimated in the 10s B.C. (Table 1). Caesar's Gallic captives and trophy type (RRC 468) account for only $2.21 \%$ of the total hoard material from the decade. This marks a significant decline compared to the previous decades. All of the examples are of RRC 468.1 and so it is not possible to continue to track the relative frequencies of RRC 468.1 and RRC 468.2 in proportion to one another. Nevertheless the lack of examples of RRC 468.2 in hoard material from the 10s B.C. is further indicative of its much smaller issue size in comparison with RRC 468.1. M. Poblicius and Cnaeus Pompey's Hispania series (RRC 469) appears at a frequency of $1.48 \%$ in the hoard material. This marks a slight increase compared to $1.08 \%$ in the 30 s and 20s B.C. material. No examples of M. Minatius Sabinus and Cnaeus Pompey's series showing personifications of Spanish cities (RRC 470) feature at all in a further indication of the exceptionally small size of the issue compared to the other two-coin series considered in this study.

A breakdown of the relative frequencies of Caesar's coin series (RRC 468) and M. Poblicius and Cnaeus Pompey's coin series (RRC 469) in individual hoards from the Iberian Peninsula with a closure date in the 10 s B.C. is provided below (Fig. 6). While the frequency of RRC 468 and RRC 469 is broadly similar in the Barroca do Antero (81 coins) and Penamacor (84 coins) hoards, there is a significant difference in their frequency in Albacete, the largest hoard collated from the decade (323 coins) (Table 1). RRC 469 appears in this hoard $(0.31 \%)$ at approximately a quarter of the frequency of Caesar's RRC 468 series (1.24\%). This further stresses the consistent significant gulf in size between the Caesarian and Pompeian images of foreign peoples and places across the decades tracked in this study.

Luis Amela Valverde has highlighted how the highest concentration of RRC 468, RRC 469 and RRC 470 in coin

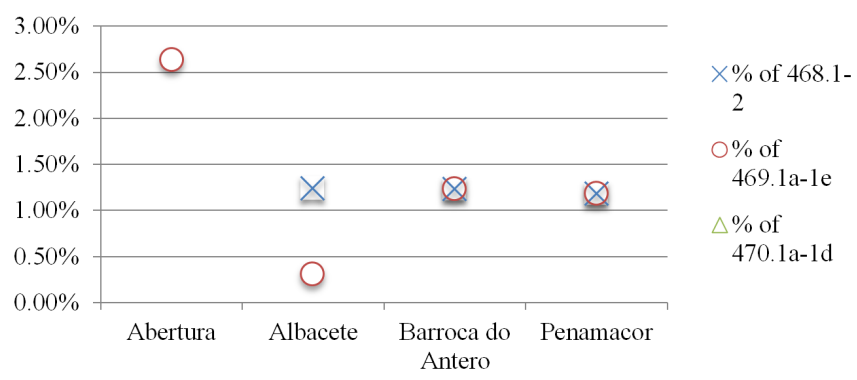

Fig. 6. chart showing percentage of RRC 468.1-2, RRC 469.1a-1e, RRC 470.1a-1d in Iberian hoards with a 1os B.C. closure date

hoards with closure dates assigned to the 40s B.C. are evident in Baetica and Lusitania, which were the regions with most involvement in the final Pompeian and Caesarian conflict in the Iberian Peninsula. ${ }^{88}$ Nevertheless Valverde demonstrates that the closure and subsequent non-recovery of these coin hoards cannot all be directly associated with contemporary events in the final campaign leading up to Munda in 45 B.C. The Empúries 1913 hoard (5 on map) and Llíria hoard (6 on map) both have estimated closure dates in 44 B.C. after the battle of Munda and in both of these cases the composition of the hoards have led to suggestions that the coins could have belonged to a veteran soldier from the campaign (Fig. 7). ${ }^{89}$ The Provincia de Córdoba (7 on map), Menoita (14 on map), Los Tejares (8 on Fig. 7 map) and Saō Bartolomeu de Meruge (9 on map) hoards which are catalogued to greater or lesser extents are similarly too late to be directly associated with the Munda campaign (Fig. 7). The four hoards all include coins that have led their closure dates to be estimated in 42 B.C. and the concealments appear to potentially be associated with continuing unrest in the region. ${ }^{90}$

Other coin hoards generally attributed to the 40s B.C. and featuring examples of RRC 468 or RRC $469-470$ cannot be securely connected to the immediate contemporary circumstances in the months around the Munda campaign because their compositions are quite significantly unknown. Only 76 of the original 100 coins known from the Sendinho da Senhora hoard (4 on map) have been studied, the latest of which is RRC 469. Julia Chinchilla Sanchez suggests that the now missing coins from this hoard would have been the best preserved and the most recently minted, which would imply a later closure date than has generally been ascribed to Sendinho da Senhora on the basis of the known coinage from it. ${ }^{92}$ Similarly only 28 out of the original 42 coins could

\footnotetext{
88 VALVERDE 2010, 25.

89 RIPOLLĖS 1982, 315 (Llíria); CAMPO 1999, 74 (Empúries 1913).

90 VALVERDE 2010, 12, 14, 15, 30.

${ }^{91}$ Blank outline map of the Iberian Peninsula that forms the basis of the maps presented in this article is reproduced and amended for the purposes of this study with permission from Ancient World Mapping Centre (http://awmc. unc.edu/wordpress/wp-content/uploads/2012/09/area_a1_blank.pdf).

92 CHINCHILLA SANCHEZ 1982, 117
} 


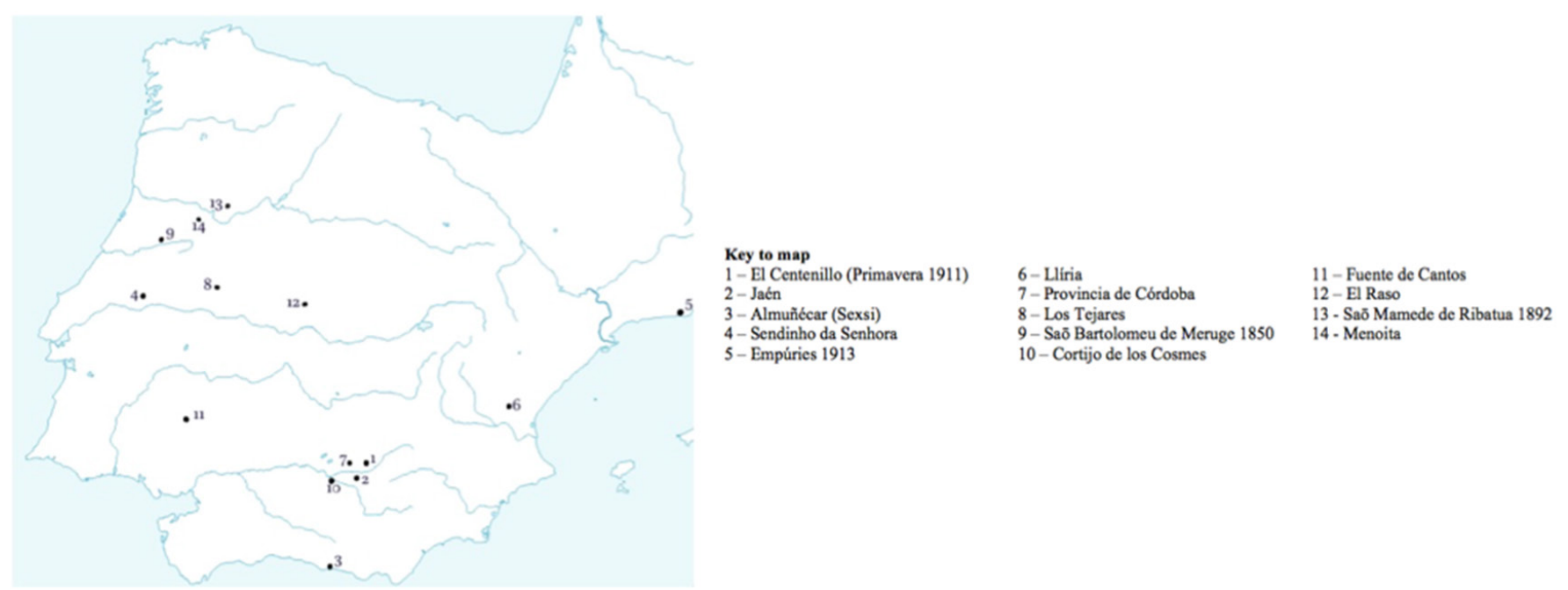

Fig. 7. map showing approximate location of coin hoards with an estimated closure date in the 40s B.C. that contain RRC RRC 468.1-2, RRC 469.1a-1e, RRC 470.1a-1d

be examined from the Almuñécar (Sexsi) hoard (3 on map) due to its concealment in a salting pool, which significantly impacted the preservation and subsequent study of the coins. ${ }^{93}$ While the latest identifiable example from this hoard was RRC $470.1 \mathrm{~b}$, it is insecure to attribute its concealment to the months of the Munda campaign on account of this. Given the high level of uncertainty surrounding the original composition of many of these hoards, the inclusion of RRC 468, RRC 469 or RRC 470 among the latest now known coinage from the hoard is far from a guarantee that the hoard's closure date corresponded closely with the minting of these issues during the campaign leading up to Munda.

The cataloguing of the Fuente de Cantos hoard (11 on map) is rather more complete (387 out of 390) and it similarly has a latest known coin type of RRC $468.1 .^{94}$ This has led its concealment to be directly connected with the Munda campaign. ${ }^{95}$ Nevertheless, given its incomplete state, this study does not associate it directly with the campaign at this stage. Valverde also questions the close association drawn between the concealment of the hoard and the events of the Caesarian and Pompeian campaigns on the basis of its location in the interior away from known areas involved in the conflict. $^{96}$

While the complete original make up of the Sao Mamede de Ribatua 1892 hoard (13 on map) is known and its latest coin type is Caesar's Gallic captive type (RRC 468.1), the preservation level of the latest specimens in the hoard also precludes any particularly close associations with the months around the Munda campaign. ${ }^{97}$ The most recent specimens known from the hoard display signs of considerable wear and tear from lengthy use and Chaves Tristán believes that given these signs of heavy usage, its concealment was almost certainly later than the generally attributed closure date of 45 B.C. ${ }^{98}$ In addition, the northern geographical location of

\footnotetext{
93 CHAVES TRISTÁN 1996, 441.

94 CHINCHILLA SANCHEZ 1982, 109; BLÁZQUEZ CERRATO 1987-1988, 132, no. 86, 2002, 39; VALVERDE 2010, 11. It does not contain any examples of RRC 469-470.

95 CHINCHILLA SANCHEZ 1982, 115.

96 VALVERDE 2010, 29.

97 CENTENO 1987, 135.

98 CHAVES TRISTÁN 1996, 504. The state of wear and tear was first discussed by
}

the hoard does not tie in with the known progression of the Munda campaign and Valverde consequently groups it with a series of hoards better associated with unrest elsewhere in Hispania in the years after the Munda campaign. ${ }^{99}$

Four further completely catalogued hoards remain with a closure date around the issues RRC 468 or RRC 469 (Cortijo de los Cosmes, El Centenillo (Primavera 1911), Jaén and El Raso). ${ }^{100}$ While El Raso can be geographically discounted from a direct association with the Munda campaign given its interior position in the Iberian Peninsula, an interesting albeit limited geographical pattern emerges when the remaining hoards are considered. ${ }^{101}$ All three of the coin hoards (1, 2 and 10 on the map) cluster in the region in and around Cordoba and two of the three hoards (El Centenillo (Primavera 1911), Jaén) feature examples of Cnaeus Pompey and M. Poblicius' (RRC 469) Hispania and Pompeian soldier type (Fig. 7). This limited clustering suggests a potentially highly focussed initial circulation in the region where the Pompeian forces were stationed and operating following the minting of these coin series. In addition, the El Centenillo (Primavera 1911) hoard has a secure find context at the entrance to the El Centenillo mine and is perhaps indicative of an early circulation beyond a purely military audience. ${ }^{102}$ This clustering has significant implications when it comes to offering a new interpretation of the Pompeian coin series (RRC 469-470).

CENTENO 1987, 135. VALVERDE 2010, 12 discusses scholarship connecting it to a closure date associated with Augustus' campaigns in northern Spain.

99 VALVERDE 2010, 29, 32

100 Cortijo de los Cosmes - latest coin - RRC 468.1, El Centenillo (Primavera 1911) - latest coin - RRC 469.1, Jaén - latest coin - RRC 469.1, El Raso - latest coin RRC 468.1. CHAVES TRISTÁN 1996, 430 notes that while it cannot now be stated definitively how many were originally in the El Centenillo (Primavera 1911) hoard, it is probable that they were mostly preserved. Ibid. further discusses the good condition of RRC 469 which suggests it hardly circulated at all, further indicative of a very rapid concealment of it after minting.

101 VALVERDE 2010, 30 disagrees with associating El Raso with the civil war engagements. Ibid., 29 argues that Cortijo de los Cosmes, El Centenillo (Primavera 1911) and Jaén are the only ones to directly correspond with the Munda campaign.

102 CHAVES TRISTÁN 1996, 430 states that ownership of the hoard has generally been ascribed to a worker in the mine. 


\section{COMPOSITIONS IN CONTEXT}

In light of the hoard evidence, this study considers how the different images of foreign peoples and places projected by the Caesarian and Pompeian sides in the Iberian Peninsula would have been received within the contemporary context of their activities in the region. Caesar's use of the Gallic military trophy and captive imagery (RRC 468) represented a continuation of a wider emphasis on this imagery in Caesarian coinage both in Rome and in travelling mints on campaign. ${ }^{103}$ The Gallic captive imagery allowed Caesar to reference his own military prowess and success without drawing direct attention to the on-going civil war conflict. In the Iberian Peninsula, the coin series in question was minted to help partially fund the significant payment required for Caesar's troops on campaign and this is reflected in the comparatively high frequency of the emission evident in the extant hoard material discussed $(5.17 \%$ in the 40 s B.C., $5.59 \%$ in the 30 s and 20 s B.C.). ${ }^{104}$ The composition of the submissive Gallic captive and military trophy closely echoes similar imagery adopted by Caesar earlier in the civil war to pay his troops around about the time of the battle of Pharsalus. ${ }^{105}$ David Sear suggests that the adoption of the familiar Gallic trophy and captive in this specific Hispanic campaign context would have been intended to "revive memories of 'the good old days' in the hearts of his seasoned veterans". ${ }^{106}$ He further posits that Caesar's troops would have been growing fatigued by several years of repeated engagements with the Pompeians and that they would have been in need of encouragement to maintain their discipline and focus in pursuit of final victory. ${ }^{107}$

The hoard evidence demonstrates that the Caesarian coin series (RRC 468) already had a geographically widespread circulation in the Iberian Peninsula within the 40s B.C. (Fig. 8). Marta Campo has highlighted the speed with which Roman coinage, especially silver, could circulate and subsequently integrate into local circulation in Hispania after minting due to movement of the army and its economic interaction with the local population. ${ }^{108}$ Beyond the immediate military audience for whom the series was originally intended, a contemporary local audience member could have regarded the image of the dominated foreign captives bluntly emblazoned with the legend CAESAR as a reflection of the acts of suppression and violence experienced at his hands by many communities during the final stages of the civil war conflict. ${ }^{109}$ This was particularly true in Hispania Ulterior where the final stages of the civil war conflict in the Iberian Peninsula were focussed. ${ }^{110}$ Caesar's siege of Ategua,

\footnotetext{
${ }_{103}$ See for example RRC 448.1-3; RRC 450; RRC 452.1, 2, 4.

104 CHAVES TRISTÁN 2005, 235 suggests additional measures by which the Pompeian and Caesarian factions would have supplemented the vast payment of their troops beyond the minting of their own coinage.

105 RRC 452. 1, 2, 4. Crawford 1974, 467 dates it from 13 July 48 B.C. to 47 B.C. while Sear 1998, 9-10 dates them after the battle of Pharsalus on 9th August 48 B.C.

106 SEAR 1998, 40.

107 Ibid.

108 CAMPO 1999, 74. For further on the army's monetary interaction and trading with the local population, see Ibid., 73

${ }_{109}$ Many although not all - LÓPEZ CASTRO 2007, 112 describes the support that many formerly Phoenician coastal cities in Hispania Ulterior gave to Caesar during the civil war.

${ }^{110}$ For further on the campaign in the region prior to the battle of Munda, see
}

for example, is noted as having resulted in the ravaging of their land and following his victory over the Pompeian forces at Munda, Caesar aggressively levied tribute and expropriated land from local communities that had opposed him in the region by standing alongside Pompey. ${ }^{111}$ It can be assumed that these went hand in hand with further acts of Caesarian suppression not referenced in the pro-Caesarian sources contemporary to the conflict. In addition, Caesar undertook a punitive programme of colonisation in Hispania Ulterior after victory at the battle of Munda. ${ }^{112}$ Seven Caesarian coloniae were set up across Hispania Citerior (2 coloniae) and Hispania Ulterior (5 coloniae). ${ }^{113}$ At least four of the five known Caesarian foundations sited in Hispania Ulterior are known to have supported the Pompeians in the civil wars and the colonisation seems to have been enacted as a punishment on those communities. ${ }^{114}$

In contrast with the emphasis on the submission and oppression of the foreign figure that is evident in the Caesarian type, the composition of the two Pompeian coin series (RRC 469, RRC 470) depicting personifications of local places appears far more focussed on appealing to a localised audience within the area. These personifications were predominantly shown on an equal footing and working in tandem with their Pompeian counterparts. The undoubtedly far smaller size of these Pompeian issues compared to their Caesarian counterpart (1.3\% compared to $5.17 \%$ in the 40 s B.C. hoard material, $1.13 \%$ compared to $5.59 \%$ in the 30 s and 20s B.C. material hoard material) means that the two coin series would have been wholly insufficient to cover the entire pay of the Pompeian forces in this final phase of the conflict. ${ }^{115}$ Chaves Tristán suggests that the bulk of the pay provided to the Pompeian legions in Hispania during this period would in fact have consisted of 'old' coinage obtained by various means from bankers, provincials and remaining faithful supporters in Rome. ${ }^{116}$ Nevertheless, the small size of the two issues coupled with their composition and RRC 469's apparently close initial circulation pattern in hoards in and around Cordoba (El Centenillo (Primavera 1911), Jaén) suggest that a desire to project a specific message to a very niche local audience drove the production of the series.

A belief in the strength and longevity of a patronal relationship between Pompey and communities in Hispania has informed standard interpretations of the two Pompeian

for example MELCHOR GIL 2005.

111 Cass. Dio 43.34 (Ategua), 43.39 (consequences after Munda).

112 See for example CABALLOS RUFINO 2010, 66-68. Cass. Dio 43.39 specifies that Caesar's course of punishment for a hostile community involved reducing or depriving them of territory, increasing taxation and moving settlers into their territory. Pompey undertook similar tactics in Hispania after the Sertorian War. See for example PINA POLO 2009 which reinterprets Pompey's foundation of Pompelo as an act of imposition and domination.

113 RICHARDSON 2001, 253. Ibid. lists the five in Hispania Ulterior as Hasta, Hispalis, Urso, Ucubi and Itucci. Ibid. names Tarraco and Carthago Nova as the two from Hispania Citerior.

114 Ibid.

115 CHAVES TRISTÁN 2005, 229. VALVERDE 2010, 25-26 also notes the significant disparity in size between RRC 468 and RRC 469-470.

116 CHAVES TRISTÁN 2005, 229. Ibid., 235 notes that both sides during the civil war appear to have used all possible methods to obtain wealth to facilitate the continuation of payment to troops e.g. through alliances, extra taxation or fines, looting, loans, funding from supporters. CAMPO 1999, 64 discusses the Empuries veteran's hoard and notes how its composition strongly indicates that military emissions only covered a portion of a soldier's pay. 


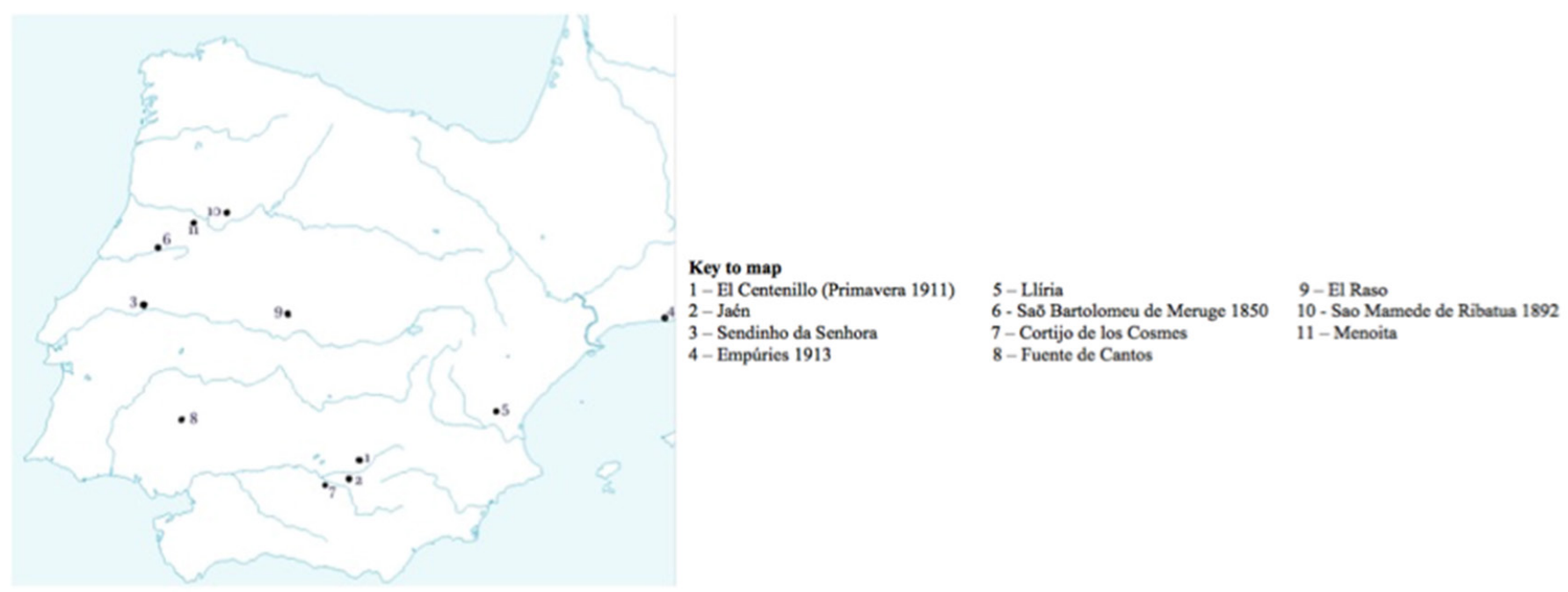

Fig. 8. map showing coin hoards with an estimated closure date in the 40s B.C. that contain RRC 468.1-2

coin series (RRC 469, RRC 470) which regard it as an appeal by Cnaeus Pompey to a pre-existing and strong support base that stemmed from his father's activity in the region during the Sertorian War. ${ }^{117}$ Traditional scholarship regards the Iberian Peninsula as a longstanding stronghold of Pompeian loyalty and clientelae with a legacy stemming from the actions of Pompeius Strabo and later consolidated by Pompey Magnus during the Sertorian War. ${ }^{118}$ Recently, Valverde argued that these networks of patronage would have been maintained in the intervening decades between the Sertorian and civil wars by a series of intermediaries acting on Pompey's behalf. ${ }^{119}$

Francisco Pina Polo recently closely scrutinised the standard assumption of the widespread and enduring nature of this Pompeian network of patronage in Hispania. ${ }^{120}$ While Pompey had granted rewards to communities that had supported him during the Sertorian War, he had also had to fight fiercely against many local communities. ${ }^{121}$ Towns in Hispania such as Clunia, Osca, Termes, Calagurris and Uxama all maintained staunch resistance to Pompey even after the death of Sertorius. ${ }^{122}$ Archaeological evidence from the Ebro valley attests to significant levels of destruction and

\footnotetext{
117 WELCH 2002, 18-19 argued that the composition of the denarii indicated the "close relationship between the army and the Spanish cities" and the use of "his famous father as an essential feature in his claims to the right to lead an army against Caesar". See also VALVERDE 2000, 17-18, 2013, 236; LOWE 2002, 72; WELCH 2012, 100.

118 See for example BADIAN 1958, 278; MILLÁN 1965; VALVERDE 2000, 9, 18, 2002, 2013, 236; MELCHOR GIL 2005, 362. VALVERDE 2002, 87 goes even further back and suggests that Q. Pompeius (cos. 141 and governor of Hispania Citerior) could have made the Pompeius name known amongst the local population and established initial contacts which were built upon by descendants during their time in the region.

119 VALVERDE 2002, 316.

120 See for example PINA POLO 2008, 2017. BERDOWSKI 2017, 167 also critiques the assumed significance of the support of Pompeian clientele, arguing that while "undoubtedly this was an important factor...it should not be exaggerated. The composition of the support for the Pompeians and the Casarians in Hispania Ulterior was a derivative of a multitude of factors, and the ubiquitous anti-Caesarian mood in the province widely accepted by scholars is certainly an overstatement".

121 PINA POLO 2008, 44.

${ }_{122}$ Ibid., 2017, 275. Flor. 2.10 notes that the population of Calagurris suffered extreme starvation before their capitulation; Val. Max. 7.6 describes how the
} citizens of Calagurris resorted to cannibalism rather than surrender. abandonment of settlements during the conflict. ${ }^{123}$ For many of them it is now difficult to establish which were razed by Pompeian and which by Sertorian forces but it nevertheless attests to the brutality experienced by indigenous populations during the conflict. Archaeological evidence for the known Pompeian sack of Valentia provides one example of definitive evidence of extreme brutality against local communities on the part of the Pompeian troops. ${ }^{124}$ Pina Polo additionally highlights the punishments meted out by Pompey at the end of the Sertorian War towards indigenous peoples that included the forced deportation of the Vettones, Arevaci and Celtiberians. ${ }^{125}$ Pina Polo argues that

"although to some Hispanians Pompey was from then on a patronus, many others viewed him as a destroyer and a representative of the Roman state. Pompey may have left behind clients in Hispania but he certainly left plenty resentment and an important number of enemies."126

Pina Polo further argues that it is incorrect to consider the clientele relationships in the provinces as encompassing entire communities but that instead it might have "been a case of personal relationships between the Roman generals and certain indigenous elites." 127 This would have meant that proportionally the number of individuals with a loyalty towards Pompey from a patronal relationship would have been small. ${ }^{128}$ In addition, these relationships did not automatically necessitate a stable and unchanging association. Pina Polo draws an astute comparison with the enactment of patronage in Rome where

"a client could have several patrons and there is no

\footnotetext{
23 PINA POLO 2008, 44, 2017, 276.

${ }^{124}$ ALAPONT MARTIN/CALVO GÁLVEZ/RIBERA I LACOMBA 2010. Sall. Hist. 2.98 references the destruction of Valentia.

125 PINA POLO 2017, 275-276.

126 Ibid. 2008, 44. Ibid. 2017, 276 argues that it was not the case that in defeat a people automatically became part of the clientelae of the imperator who had defeated them but that the "deditio of a town or people involved their subjugation to Rome (sub imperio populi Romani), but did not entail the establishment of a personal or collective relationship with the victor".

127 Ibid. 2008, 47.

128 Ibid. 2017, 277.
} 
evidence that this relationship involved unconditional political support as if a contract had been signed. The same must have happened in the provinces, as evidenced by the changing behaviour of peoples and cities in Hispania during the military conflict between Pompey and Caesar, or for example in particular the Balbi's actions, initially supportive of Pompey, from whom they obtained Roman citizenship, but later on they were firm supporters of Caesar during the civil war."129

Pina Polo further scrutinises the longevity and depth of loyalty of any Pompeian networks of patronage that did exist in Hispania after the end of the conflict against Sertorius. While Pompey Magnus had gained control of the two Spanish provinces following the conference at Lucca in 56 B.C., his legates managed them indirectly on his behalf while he remained in Rome throughout the remainder of the decade. ${ }^{130}$ There is no specific indication of any strong cultivation or maintenance of clientele networks in the Iberian Peninsula by Pompey's legates during this period..$^{131}$ During the initial civil war hostilities in the Iberian Peninsula Caesar notes the significant benefits brought to his cause by the support of indigenous communities such as the Tarraconenses, Iacetani and Ausetani. ${ }^{132}$ A cohort of the indigenous Iluravonenses also abandoned the Pompeians in favour of joining Caesar's army. ${ }^{133}$ Pina Polo notes how these were peoples from the north-east of Hispania in Hispania Citerior, presumably an area where Pompey had had a certain following of clients and allies following the Sertorian War, however there is no evidence to suggest that these communities significantly supported Pompey's side during the initial phases of the civil war. ${ }^{134}$

Pompey Magnus himself had never even set foot in Hispania Ulterior where RRC 469 and RRC 470 were minted and a lack of a strong and consistent consensus in favour of the Pompeians within many of the prominent cities of Hispania Ulterior is evident when the progression of events in the conflict there is considered more closely. ${ }^{135}$ Dio makes it clear even when describing Cnaeus Pompey's initial arrival in the region that support for the Pompeian side was far from universal and that while some cities joined his side immediately, others had to be forcefully subjugated to the cause. ${ }^{136}$ This impression of divided loyalties continues following Caesar's arrival in Hispania Ulterior. During the Caesarian siege of the supposedly pro-Pompeian city of Ategua, for example, repeated attempts were seemingly made by elements within the city to surrender and to inform Caesar of the defence preparations being made for the city. ${ }^{137}$ Dissension in the city in favour of capitulating to Caesar was severely punished by the Pompeian troops who even went so far as to publicly slit the throats of

\footnotetext{
129 Ibid., 48.

130 PINA POLO 2008, 44, 2017, 273 notes that "a client-patron relationship had to be nurtured to be of any use".

131 Ibid. 2008, 44.

132 Caes. BCiv. 1.60.

133 Ibid.

134 PINA POLO 2008, 45, 46, 2017, 271

135 Ibid. 2017, 280. See for example LOWE 2002, 74 for discussion of the divisions within communities.

${ }_{136}$ Cass. Dio 43.30.

${ }^{137}$ BHisp. 13, 18.
}

dissenters on the city walls. ${ }^{138}$ Similar events took place in neighbouring Ucubi where Cnaeus Pompey ordered the hunt for and death of Caesarian supporters. ${ }^{139}$ References are also made to clashes between members of the local elite in Ursao that were in favour of either the Caesarian or the Pompeian sides. ${ }^{140}$ Even in Cordoba, the most prominent city under Pompeian control in Hispania Ulterior during this phase of the civil war, there is evidence for a duality of sentiment and opinion with presumably elite figures from the city repeatedly sending Caesar supportive deputations requesting that he send his legions to back them. ${ }^{141}$ Whilst some of these Caesarian elements were undoubtedly in a minority within their communities, it is nevertheless indicative of the unsettled nature of the local communities and a lack of an overwhelming consensus in the region in favour of supporting the Pompeian cause. ${ }^{142}$

Given the significant question marks around Pompeian patronage in Hispania Ulterior during the civil war, Pina Polo reframes the events there as an opportunistic move by the Pompeians. He views their move into the region in light of the significant unpopularity of the Caesarian governor Cassius Longinus who had sparked an open rebellion that not even a change of governorship to the Caesarian Gaius Trebonius could quell. ${ }^{143}$ The region therefore provided potentially fertile ground for a stand against Caesar's forces where Pompeian forces could potentially be swelled and aided by tapping into a strong local sentiment against the previous Caesarian governance of the region.

This study offers a reinterpretation of the Pompeian series of coins (RRC 469, RRC 470) in light of the significant questions about the true nature and the strength of Pompeian influence and support in the region during this phase of the civil war. Rather than regarding the imagery as courting a strong existing network of Pompeian support, it regards it as an appeal to elements within a potentially wavering host community to regard themselves as working together in a common cause against the Caesarians in the region. This study argues that the Pompeian denarii series would have targeted the influential elites amongst the local population. These elements appear to have shown significant potential to be split regarding whether to support the Caesarian or Pompeian sides. ${ }^{144}$ Nevertheless as influential figures in their local community who regularly served as key interlocutors with Roman magistrates in their day-to-day lives through the likes of the conventus civium Romanorum, they also provided the most potential in terms of cultivating a network of supporters against Caesar. ${ }^{145}$ Strong impetus behind the initial rebellion in Hispania Ulterior seems to have come

\footnotetext{
138 BHisp. 15. See also BHisp. 16, 18 for further examples of dissension in Ategua.

139 BHisp. 20, 21

140 BHisp. 22

${ }^{141}$ RODRIGUEZ NEILA 2005, 324. See also BHisp. 2, 34

142 RODRIGUEZ NEILA 2005, 324 notes that the pro-Caesarian elements in Cordoba were undoubtedly in the minority given that they closed their doors to him despite having opened them to him three years earlier.

143 PINA POLO 2017, 281.

144 As in the cases of Ategua, Ucubi, Ursao and Cordoba discussed above. 145 RODRIGUEZ NEILA 2005, 321 notes that in the two cities in the region (Cordoba and Hispalis) which had a conventus civium Romanorum, the elite figures on the conventus served as the main interlocutor with Roman magistrates.
} 
from local elite figures who were the most affected by the Caesarian governor Cassius Longinus' fierce and unpopular attacks on their wealth. ${ }^{146}$ Conspirators in an earlier failed attempt to assassinate Longinus were prominent and wealthy individuals from Italica and Cordoba. T. Quinctius Scapula and Quintus Aponius who led the rebellion prior to the arrival of Cnaeus Pompey Jr are also likely to have been equites from Cordoba. ${ }^{147}$ Scapula himself reportedly handed over control of the rebellion to Cnaeus Pompey.

The local elites were therefore a prime constituency to opportunistically target through the medium of coinage in order to cultivate support against Caesar. The imagery adopted in the two Pompeian coin series minted in the latter stages of the civil war campaign displays representatives of the Pompeian forces and local communities working in tandem towards a common goal and expresses a misguided confidence in their joint ability to achieve victory.

\section{CONTRASTING IMAGES}

The Pompeian and Caesarian coin series produced contemporaneously in Hispania provide a unique vacuum in which to directly compare and contrast their usage of images of foreign peoples and places on coinage during the civil wars. Caesar's use of the image of the Gallic captive and trophy formed one part of a wider programme of Gallic figural and non-figural imagery adopted elsewhere in Caesarian coinage which allowed him to demonstrate his military prowess without drawing direct attention to the civil war conflict. Hoard evidence demonstrates the significant scale of RRC 468 in Hispania compared to the two Pompeian series. For a local audience in Hispania Ulterior the expression of military predominance evident in imagery that was in widespread circulation might have felt all too reflective of acts of suppression experienced at Caesar's hands by many communities during the periods of conflict there. Whilst the two Pompeian series (RRC 469-470) were produced on a far smaller scale than their Caesarian counterpart, hoard evidence is similarly suggestive when it comes to considering the potential impact on an ancient viewer of imagery that demonstrated far greater sensitivity towards a local audience. The clustering of RRC 469 in and around the area of Cordoba is suggestive of a potential audience targeting towards an elite whose Pompeian support was far less secure than has traditionally been assumed. ${ }^{148}$

\footnotetext{
146 BAlex. 56 describes the severe resentment stirred up by some of Cassius Longinus' financial impositions. RODRIGUEZ NEILA 2005, 343 sees the resentment of the rebelling legio II and legio vernacula as stemming from Caesar's request that they transfer to Africa and move away from their own province and established material interests. Ibid. argues that this is played down in the account given in BAlex. to protect Caesar's interests. If this is indeed correct then different motivations for rebellion can be ascribed to different elements of contemporary local society.

147 BAlex. 52 (assassination attempt), RODRIGUEZ NEILA 2005, 342 (Aponius and Scapula).

${ }_{148}$ Research towards this article was undertaken at the Goethe-Universität Frankfurt am Main with grateful thanks to the DAAD for funding towards the project and to Fleur Kemmers for her feedback and support. Many thanks also to Andreas Murgan (Friedrich-Alexander-Universität ErlangenNürnberg), Marietta Horster (Johannes Gutenberg-Universität Mainz), Karin Maurer-Lenius (Albert-Ludwigs-Universität Freiburg) and the Ancient World Mapping Center for assisting with permission for the reproduction of figures in this article. I am also very grateful to Ben Naylor for his advice.
}

\section{REFERENCES}

ALAPONT MARTIN/CALVO GÁLVEZ/RIBERA I LACOMBA 2010

Alapont Martin, L./Calvo Gálvez, M./Ribera i Lacomba, A., La destrucciòn de Valentia por Pompeyo (75 a.C.), Quaderns de difusió arqueològica 6, 1-39.

DE ALARCĀO 1999

deAlarcāo, J., O contexto histórico dos tesouros republicanos romanos em Portugal. In: Centeno, R.M.S./Garcia-Bellido, M.P./Mora, G.P. (eds.), Rutas, ciudades y moneda en Hispania (Madrid: Consejo Superior de Investigaciones Cientificas), 1-8.

ARCE 1980

Arce, J., La iconografia de 'Hispania' en epoca romana, Archivo Español de Arqueología 53, 77-102.

BADIAN 1958

Badian, E., Foreign clientelae (264-70 B.C.) (Oxford: Clarendon Press).

BARBOSA 1998-2002

Barbosa, M.B.C., Tesouros monetários romanos em Portugal: da República ao Reinado de Augustus, Nummus 21-25, 7-144.

BERDOWSKI 2017

Berdowski, P., RRC 469-470 and the revolt in Hispania in 46 B.C.E., Annali Istituto Italiano di Numismatica 63, 163-178.

BLÁZQUEZ CERRATO 1987-1988

Blázquez Cerrato, C., Tesorillos de la moneda republicana en la peninsula ibérica. Addenda a Roman Republican Coin Hoards, Acta Numismatica 17-18, 105-142.

BLÁZQUEZ CERRATO 1992

Blázquez Cerrato, C., La dispersion de las monedas de Augusta Emerita (Merida: Museo Nacional de Arte Romano).

BLÁZQUEZ CERRATO 2002

Blázquez Cerrato, C., Circulación monetaria en al area occidental de la peninsula ibérica: la moneda en torno al "Camino de la Plata" (Montagnac: Éditions Monique Mergoil).

\section{BRILLIANT 1963}

Brilliant, R., Gesture and rank in Roman art: the use of gestures to denote status in Roman sculpture and coinage (New Haven: Connecticut Academy of Arts and Sciences).

\section{BUTTREY 1960}

Buttrey, T.V., The denarii of Cn. Pompeius Jnr. and M. Minatius Sabinus, American Numismatic Society Museum Notes 9, 75-94.

CABALLOS RUFINO 2010

Caballos Rufino, A., Colonizzazione cesariana, legislazione municipal e integrazione provinciale: la Provincia Hispania Ulterior. In: Urso, G. (ed.), Cesare: precursore o visionario? Atti del convegno internazionale, Cividale del Friuli, 17-19 settembre 2009 (Pisa: Edizioni ETS), 63-84.

\section{CAMPO 1999}

Campo, M., Els exércits i la monetitzaciò d'Hispània (21845 a.C.). In: Gabinet Numismàtic de Catalunya, Moneda $i$ exèrcits: III Curs d'Història Monetària d'Hispània (Barcelona, MNAC), 59-82.

\section{CAMPO 2002}

Campo, M., Sobre dos dépositos de denarios romanorepublicanos procedentes de Emporion. In: $X$ Congreso Nacional de Numismática. Actas. (Albacete: Museo Casa de la Moneda), 327-333.

CENTENO 1987

Centeno, R.M.S., Circulaçao monetaria Noroeste de Hispania até 192 (Porto: Dissertaçao de Doutoramento em PréHistória e Arqueologia apresentada à Faculdade de Letras da Universidade do Porto).

CHAVES TRISTÁN 1996 
Chaves Tristán, F., Los Tesoros en el Sur de Hispania (Sevilla: Fundación El Monte).

CHAVES TRISTÁN 1999

Chaves Tristán, F., De tesoros fragmentados y otros problemas: nuevos hallazgos de denarios republicanos en la Hispania Ulterior. In: Villar, F./Beltrán, F. (eds.), Pueblos, lenguas y excrituras en la Hispania prerromana (Salamanca: Institución 'Fernando el Católico' Excma Diputación de Zaragoza, Ediciones Universidad Salamanca), 141-172.

CHAVES TRISTÁN 2005

Chaves Tristán, F., Guerra y moneda en la Hispania del Bellum Civile. In: Melchor Gil, E./Mellado Rodriguez, J./ Rodriguez-Neila, J.-F. (eds.), Julio César y Corduba: tiempo y espacio en la campan̆a de Munda (49-45 a.C.) (Cordoba: Universidad de Cordoba), 207-245.

CHINCHILLA SANCHEZ 1982

Chinchilla Sanchez, J., El tesorillo de denarios romano -republicano de Fuente de Cantos (Badajoz), Acta Numismatica 12, 97-125

\section{CODY 2003}

Cody, J.M., Conquerors and the conquered on Flavian coins. In: Boyle, A.J./Dominik, W.J. (eds.), Flavian Rome: culture, image, text (Leiden: Brill), 103-124.

CRAWFORD 1974

Crawford, M.H., Roman Republican Coinage (London: Cambridge University Press).

GOZALBES 2001

Gozalbes, M., El tesorillo republican de Castilblanques (Cortes de Pallás, Valencia), Archivo de prehistoria levantina 24, 351-355.

GRUEBER 1970

Grueber, H.A., Coins of the Roman Republic in the British Museum Volume II: Coinages of Rome (continued), Roman Campania, Italy, the Social War and the provinces (Oxford: British Museum).

HOLLSTEIN 1994

Hollstein, W., Apollo und Libertas in der Münzprägung des Brutus und Cassius, Jahrbuch für Numismatik und Geldgeschichte 44, 113-133.

HURTADO MULLOR/LLEDÓ CARDONA 2005

Hurtado Mullor, T./Lledó Cardona, N., El Tesoro de denarios republicanos en Sant Miquel de Llíria. In: Ribera i Lacomba, A./Ripollès Alegre, P.P., Tesoros monetarios de Valencia y su entorno (Valencia: Ajuntament de Valencia), 61-82.

KOPIJ 2012

Kopij, K., Propaganda war over Sicily? Sicily in the Roman coinage during the civil war 49-45 B.C., Studies in Ancient Art and Civilization 16, 167-182.

KOPIJ 2015

Kopij, K., The use of local identities in the monetary propaganda of the Pompeians during the war with Caesar 49-48 B.C., Journal of Ancient History and Archaeology 2.3, 32-37.

LÓPEZ CASTRO 2007

López Castro, J.L., The western Phoenicians under the Roman Republic: integration and persistence. In: van Dommelen, P./ Terrenato, N. (eds.), Articulating local cultures: power and identity under the expanding Roman Republic (Portsmouth: Journal of Roman Archaeology), 103-125.

LOWE 2002

Lowe, B.J., Sextus Pompeius and Spain: 46-44 B.C. In: Powell, A./Welch, K. (eds.), Sextus Pompeius (London: Duckworth), 65-102.

MACDOUGALL 2017

MacDougall, E., Representations of empire: images of foreign peoples and places on Roman coinage (138 B.C.-98 A.D.) (St
Andrews: PhD thesis in the School of Classics, University of St Andrews).

MELCHOR GIL 2005

Melchor Gil, E., Entre Corduba y Munda: la campaña military del 45 a.C. y su desarrollo en la campiña de Cordóba. In: Melchor Gil, E./Mellado Rodriguez, J./Rodriguez-Neila, J.F. (eds.), Julio César y Corduba: tiempo y espacio en la campaňa de Munda (49-45 a.C.) (Cordoba: Universidad de Cordoba), 361-379.

\section{MILLÁN 1965}

Millán, C., Aspectos hispanicos de la familia Pompeia, Contresso Internazionale di Numismatica. Roma 11-16 Settembre 1961. Vol. II. Atti (Roma: Istituto Italiano di Numismatica), 293-300.

\section{MOMMSEN 1870}

Mommsen, T., Histoire de la monnaie romaine. Tome second (Paris: J. de Witte).

\section{NEWMAN 1990}

Newman, R., A dialogue of power in the coinage of Antony and Octavian (44-30 B.C.), American Journal of Numismatics 2, 37-63.

PINA POLO 2008

Pina Polo, F., Hispania of Caesar and Pompey. A conflict of clientelae? In: Paz Garcia-Bellido, M./Mostalac, A./Jiménez, A. (eds.), Del imperium de Pompeyo a la auctoritas de Augusto. Homenaje a Michael Grant (Madrid: Consejo Superior de Investigaciones Cientificas), 41-48.

PINA POLO 2009

Pina Polo, F., Sertorio, Pompeyo y el supuesto alineamiento de los Vascones con Roma. In: Andreu Pintado (ed.), Los Vascones de las fuentes antiguas: en torno a una etnia de la antigüedad peninsular (Barcelona: Publicacions i edicions de la universitat de Barcelona), 195-214.

PINA POLO 2017

Pina Polo, F., Pompey's clientele in Hispania. A reappraisal. In: Haake, M./Harders, A. (eds.), Politische Kultur und soziale Struktur der Römischen Republik: Bilanzen und Perspektiven. Akten der internationalen Tagung anlässlich des 70. Todestages von Friedrich Münzer (Münster, 18-20 Oktober 2012 (Stuttgart: Franz Steiner Verlag), 269-285.

\section{RICHARDSON 2001}

Richardson, J.S., Social mobility in the Hispanic provinces in the Republican period. In: de Blois, L. (ed.), Administration, prosopography and appointment policies in the Roman Empire. Proceedings of the first workshop of the International Network Impact of Empire (Roman Empire, 27 B.C.-A.D. 406), Leiden, June 28-July 1, 2000 (Amsterdam: J.C. Gieben), 246-254.

\section{RIPOLLÈS 1982}

Ripollès, P.P, La circulación monetaria en la tarraconense mediterránea (Valencia: Servicio de investigación prehistórica).

\section{RODRIGUEZ NEILA 2005}

Rodriguez Neila, J.F., Corduba entre cesarianos y pompeyanos durante la Guerra civil. In: Melchor Gil, E./ Mellado Rodriguez, J./Rodriguez-Neila, J.-F. (eds.), Julio César y Corduba: tiempo y espacio en la campaňa de Munda SEAR 1998 (49-45 a.C.) (Cordoba: Universidad de Cordoba), 311-360.

Sear, D.R., The history and coinage of the Roman imperators (London: Spink).

\section{SYDENHAM 1952}

Sydenham, E.A., The coinage of the Roman Republic (London: Spink)

VALVERDE 1990-1991

Valverde, L.A., La amonedación pompeyana en Hispania. Su utilización como medio propagandistico y como reflejo 
de la clientela de la gens Pompeia, Faventia 12-13, 181-197. VALVERDE 2000

Valverde, L.A., Acuñaciones de Cneo Pompeyo hijo en Hispania, Numisma 244, 7-33.

VALVERDE 2002

Valverde, L.A., Las clientelas de Cneo Pompeyo Magno en Hispania (Barcelona: Publicacions i edicions de la universitat de Barcelona).

VALVERDE 2010

Valverde, L.A., La circulación monetaria romanorepublicana de Hispania durante la segunda guerra civil según las ocultaciones de la época, Numisma 254, 7-39.

VALVERDE 2013

Valverde, L.A., La emission RRC 469 de Cneo Pompeyo hijo, Revista Portuguesa de Arqueologia 16, 227-242.

VILLARONGA 1971-1972

Villaronga, L., Tesorillo de Albacete del año 1906, Ampurias 33-34, 305-332.
VILLARONGA 1993

Villaronga, L., Tresors monetaris de la peninsula ibèrica anteriors a Augusti: repertori i analisi (Barcelona: Asociacion Numismatica Española, Societat Catalana D'estudis Numismàtics).

\section{WELCH 2002}

Welch, K., Both sides of the coin: Sextus Pompeius and the so-called Pompeiani. In: Powell, A./Welch, K. (eds.), Sextus Pompeius (London: Duckworth), 1-30.

\section{WELCH 2012}

Welch, K., Magnus Pius: Sextus Pompeius and the transformation of the Roman Republic (Swansea: The Classical Press of Wales).

\section{WOYTEK 2003}

Woytek, B.E., Arma et Nummi: Forschungen zur römischen Finanzgeschichte und Münzprägung der Jahre 49 bis $42 v$. Chr. (Vienna: Verlag der Österreichischen Akademie der Wissenschaften). 